\author{
Tor Arne Haugen \\ Høgskulen i Volda \\ Eivor Finset Spilling \\ Høgskulen i Volda
}

DOI: http://dx.doi.org/10.5617/adno.7927

\title{
Pedagogiske tekstar om ordklassar: ei undersøking av lærebøker i norsk på 3. og 4. trinn
}

\begin{abstract}
Samandrag
Korleis blir ordklassane i norsk framstilte i lærebøker i norskfaget for 3. og 4. trinn? I læreplanen (LK06) blir ordklassar eksplisitt nemnde i kompetansemål etter 4. trinn, der det heiter at elevane skal kunne «beskrive ordklasser og deres funksjon». Eit viktig spørsmål blir då korleis ein forstår omgrepet funksjon. Tradisjonelt blir ordklassane i skulegrammatikken handsama med grunnlag i eit systemorientert grammatikksyn, og det er difor interessant å undersøke nærare korleis læreverka balanserer det systemorienterte med det funksjons- og tekstorienterte fokuset i læreplanen. Materialet omfattar pedagogiske tekstar om ordklassar i fire læreverk, og det er utført ein kvalitativ innhaldsanalyse for å få fram korleis ulike innhaldskategoriar blir vektlagde. Undersøkinga viser at alle læreverka er både systemorienterte og funksjonsorienterte, men at skilnadene i vektlegging er relativt store. Det er også skilnader når det gjeld kva for ordklassar som blir presenterte, og undersøkinga fokuserer på verb, substantiv og adjektiv, som blir handsama i alle læreverka. Det blir også funne skilnader i framstillinga av dei einskilde ordklassane. Endeleg blir det argumentert for at det kan vere vanskeleg å oppnå ei første forståing av funksjonane til ordklassane så lenge dei blir handsama åtskilt frå funksjonane dei har i setningar.
\end{abstract}

Nøkkelord: ordklassar, pedagogiske tekstar, læreplan, systemorientert tilnærming, funksjonsorientert tilnærming

\section{Pedagogical texts on parts of speech: an investigation of textbooks in Norwegian studies for the 3rd and 4th year of schooling}

\begin{abstract}
How are parts of speech presented in textbooks for Norwegian studies for the 3rd and 4th year of schooling? In the curriculum (LK06), parts of speech are explicitly mentioned in a competence aim succeding the 4th year, which states that the pupils shall be able to describe parts of speech and their functions. An important question is therefore how the notion of function is understood. In traditional school grammars, the parts of spech have been treated on the basis of a systemic view of grammar, and it is therefore interesting to investigate how textbooks balance the systemic approach with
\end{abstract}


the function- and text oriented approach in the curriculum. The material of the investigation includes pedagogical texts from four textbook series, and a qualitative content analysis has been carried out to reveal how different content categories are emphasised. The investigation shows that all series of textbooks are oriented both towards systemic and functional approaches, but also that there are substantial differences in emphasis. There are also differences when it comes to which parts of speech are included in the textbooks, and since all textbook series include verbs, nouns and adjectives, the further investigation focused on these classes. Differences were also found as to how the individual parts of speech are presented. Finally, it is argued that a first understanding of the functions of the parts of speech might be difficult to achieve as long as they are treated apart from their functions in clauses.

Keywords: parts of speech, pedagogical texts, curriculum, systemic approach, functional approach

\section{Innleiing}

Korleis blir ordklassane i norsk framstilte i lærebøker i norskfaget for 3. og 4. trinn? Ordklasselære er ein av dei klassiske grammatiske disiplinane i skulen, og er eit av dei språkvitskaplege kunnskapsområda som er eksplisitt knytt til eit kompetansemål i læreplanen til norskfaget (NOR1-05, 2013) i Læreplanverket for kunnskapsløftet (LK06). Etter 4. trinn skal elevane kunne «beskrive ordklasser og deres funksjon» (NOR1-05, 2013, s. 7). Sjølv om formuleringa er særs knapp, er det nærliggande å tolke dette slik at elevane først og fremst skal lære om funksjonen til dei ulike ordklassane, og eit viktig spørsmål blir då korleis ein forstår omgrep som funksjon og funksjonell. I læreplanen som heilskap er det liten tvil om at lesing og skriving av tekstar er det sentrale fokuset. I beskrivinga av formålet med faget heiter det:

I norskfaget møter elevene et bredt spekter av tekster. Faget bygger på et tekstbegrep som inkluderer muntlige, skriftlige og sammensatte tekster, der skrift, lyd og bilder spiller sammen. Elevene skal lære å orientere seg i mangfoldet av tekster, og faget skal gi rom for både opplevelse og refleksjon. I løpet av opplæringen skal de lese skjønnlitteratur og sakprosa, utvikle evnen til kritisk tenking og få perspektiv på teksthistorien. Gjennom muntlig og skriftlig kommunikasjon kan de sette ord på egne tanker og stå fram med meninger og vurderinger. De skal selv produsere ulike typer tekster med hensiktsmessige verktøy, og tilpasse språk og form til ulike formål, mottakere og medier. Etter hvert vil de også kunne fordype seg i faglige emner og bli dyktigere til å formidle et faglig innhold til andre. (NOR1-05, 2013, s. 2, våre uth.)

Tekstfokuset blir også understreka når det etter 7. trinn heiter at elevane skal kunne «utføre grunnleggende setningsanalyse og vise hvordan tekster er bygd opp ved hjelp av begreper fra grammatikk og tekstkunnskap» (NOR1-05, 2013, s. 8). I dette kompetansemålet blir også grammatikken eksplisitt knytt til tekstar. 
Grammatikken spelar i LK06 først og fremst ei rolle som metaspråk i arbeid med tekst, utan at det blir presisert kva for språkvitskapleg teorigrunnlag som bør ligge til grunn for arbeidet med grammatikken i skulen, men ser ein på tilrådinga Grammatiske termer til bruk i skoleverket (2005) frå Norsk språkråd og Utdanningsdirektoratet, er dette først og fremst ei vidareføring av strukturalistisk basert terminologi, med eit tydeleg systemorientert fokus. Utgangspunktet for undersøkinga er difor følgjande spørsmål: Korleis blir systemorienterte og funksjonsorienterte tilncermingar til grammatikk balanserte i beskrivinga av ordklassane?

Materialet for undersøkinga er lærebøker i norsk for 3. og 4. trinn frå fire av dei største lærebokforlaga: Kaleido frå Cappelen Damm (Johansen \& Tovsrud, 2015, 2016), Ordriket frå Fagbokforlaget (Bjerke et al., 2013, 2014), Nye Zeppelin frå Aschehoug (Elsness, 2016, 2017) og Salto frå Gyldendal (Bjerke, Fjeld \& Svanes, 2015), til saman 30 band.

\subsection{Tidlegare forsking}

Forsking på det Selander (1988) var den første til å kalle pedagogiske tekstar, har ei relativt kort historie, men har resultert i auka fokus på slike tekstar også i Noreg (Aamotsbakken \& Knudsen, 2008; jf. Knudsen, 2013; Knudsen \& Aamotsbakken, 2010b; Selander \& Skjelbred, 2004). Selander (1988, s. 17) beskriv pedagogiske tekstar som følgjer:

Med pedagogisk text kan vi mena lärobok, läsebok, övningsbok eller ett undervisningsprogram i filmens eller videons form. Grundidén med den pedagogiska texten är att den ska återskapa eller reproducera befintlig kunskap, inte skapa ny kunskap. Det måste alltså ske ett urval och en avgränsning av det som ska återges. Dessuton måste texten struktureras i enlighet med vissa pedagogiska krav.

Omgrepet pedagogisk tekst er eit omgrep som på ingen måte er definert ein gong for alle, jf. Knudsen og Aamotsbakken (2010a), og det er i stadig endring etter kvart som ny teknologi kjem til. Likevel skulle det vere liten tvil om at lærebøker inneheld pedagogiske tekstar, og lærebøker er framleis sentrale i læringsarbeidet i skulen (Gilje, 2016). Med dei knappe kompetansemåla ein opererer med i læreplanen, er det klart at lærebøker dermed også potensielt spelar ei viktig rolle i den konkrete didaktiseringa av kompetansemåla.

Det finst ei rekke ulike inngangar til pedagogiske tekstar i lærebøker, jf. Johnsen (1999, 2001), Knudsen og Aamotsbakken (2010b) og Skrunes (2010), og fokuset vårt her er avgrensa til det fagdidaktiske: «Faglig blir spørsmålet hvordan man ser og behandler skolefaget i forhold til vitenskapsfaget. Hvilket fagsyn bygger boken på, hvilke deler av faget er valgt ut, hvor stor plass har de fått og hvordan er de rangert?» (Johnsen, 1999, s. 10).

Trass i at interessa for forsking på pedagogiske tekstar har auka dei siste tiåra, slår Juuhl, Horntvedt og Skjelbred (2010, s. 35) fast at det ikkje finst så mykje forsking på læremiddel frå tida etter Kunnskapsløftet blei innført i 2006, og som 
Bakken og Andersson-Bakken (2016, s. 5) peikar på, har dei større studiane i Noreg særleg fokusert på vurdering og val av lærebøker. I bibliografien til Juuhl et al. (2010) er det ingen arbeid som set fokus verken på grammatikk generelt, eller ordklassar spesielt.

Den grammatikkdidaktiske debatten i Noreg har i stor grad dreia seg om didaktikkens kvifor, og i mindre grad om kva og korleis (jf. Hertzberg, 1995; Myrmo, 1998), og Myhill og Watson (2014) viser at dette også har vore tilfelle i eit land som Storbritannia, jf. også Haugen (2019). Ikkje minst på bakgrunn av ei rekke effektstudiar som har vist manglande effekt av grammatikkundervisning på elevars skriving, har det vore eit stridsspørsmål om grammatikken i det heile skulle ha ein plass i skulen. I metastudien til Andrews et al. (2006) konkluderer forfattarane med at det for engelskspråklege elevar mellom 5 og 16 år ikkje ser ut til å vere nokon effekt på skriveutvikling av det dei kallar syntaksundervisning «as part of a traditional or transformational/generative approach to teaching grammar». Presiseringa av kva for grammatikkundervisning det er snakk om, er viktig, for den nyare intervensjonsstudien til Myhill, Jones, Lines og Watson (2012), tyder derimot på at grammatikk integrert i skriveundervisninga har positiv effekt på elevars skriving. Denne studien, som omfatta i alt 744 elevar, tyder på at funksjonell grammatikk integrert i skriveundervisninga har positiv effekt og fører til auka metaspråkleg medvit, særleg for dei sterkaste elevane. Myhill et al. (2012) knyter seg ikkje eksplisitt til eitt bestemt grammatikkteoretisk rammeverk, men i utdjupinga av grammatikkforståinga dei legg til grunn (Myhill, Jones, Watson \& Lines, 2013), er fokuset på grammatikk som meiningsfulle val i elevanes design av tekstar, og ho ligg såleis nær tilnærmingar som ser språksystemet og tekstlege realiseringar av det som to sider av same sak, slik som systemisk-funksjonell grammatikk (t.d. Halliday, 2014) og retorisk grammatikk (t.d. Kolln \& Gray, 2016).

Schleppegrell (2013) viser korleis funksjonell grammatikk kan integrerast i arbeid med tekstar i ein L2-kontekst og gje auka forståing for forholdet mellom system og bruk med auka metaspråkleg medvit som resultat, og ei slik tilnærming er etter vårt syn også svært relevant for L1-læring, jf. også Haugen (2019), som argumenterer for at funksjonell grammatikk har potensial for å legge til rette for djupnelæring i norskfaget.

Det finst likevel framleis lite forsking på effektar av funksjonelle grammatiske tilnærmingar, og som Macken-Horarik, Sandiford, Love og Unsworth (2015) peikar på, er dei førebels ikkje integrerte i metastudiar.

Det finst også svært lite av norske klasseroms- og læremiddelstudiar som tek føre seg grammatikk, men nokre nyare masteroppgåver har fokus på grammatikk i norskfaget (Karsrud, 2014; Sellevoll, 2016; Tiller, 2016; Trygsland, 2017; Van Duijn, 2016). To av desse inneheld analysar av læreverk, og er dermed særleg relevante for denne studien: Tiller (2016) undersøkte korleis to lærebøker på Vg1 formidlar grammatiske kategoriar og trekk som moglege verktøy i skriving av sakprega tekstar. Van Duijn (2016) samanlikna læreplanar og læreverk frå 
Nederland og Noreg, og når det gjeld dei norske, fann ho at det funksjonelle er mest vektlagt, men at systemgrammatiske tilnærmingar som bøyingsparadigme òg får ein del plass.

Eit viktig mål for undersøkinga som blir presentert under, er å gje presise mål for tilhøvet mellom ulike grammatiske innhaldskategoriar i lærebøker på trinna der elevane møter ordklassar for første gong, og for det vi i neste del skal kalle systemorienterte og funksjonsorienterte tilnærmingar.

\section{Systemorientert versus funksjonsorientert grammatikk}

Samanliknar vi læreplanens intensjon om funksjonell, tekstorientert grammatikkundervisning med den tradisjonelle tilnærminga til skulegrammatikk, som i stor grad har eit reint systemorientert fokus, har vi ein interessant motsetnad. Frå Mønsterplan for grunnskolen som kom i 1987 (M87) har ein rett nok lagt meir vekt på grammatikken som metaspråk og på bruk av grammatikken i beskriving av språkbruk (Hertzberg, 2004; Karsrud, 2014), men det er framleis i stor grad den strukturalistiske terminologien som ligg til grunn for beskrivinga av det grammatiske systemet. Det verkar rimeleg å seie at ein i alle fall med Terminologien i norsk språklære (1977) frå Norsk språkråd får strukturalismen etablert som det viktigaste teoretiske grunnlaget også for grammatiske termar i skulen i Noreg, jf. Hertzberg (1990, s. 114), og Grammatiske termer til bruk $i$ skoleverket (2005), ei ny tilråding frå Norsk språkråd og utdanningsdirektoratet, som tok inn ein del av dei nye termane frå Norsk referansegrammatikk (Faarlund, Lie \& Vannebo 1997), er ei vidareføring av eit slikt systemorientert fokus. Såleis må vi skilje mellom funksjonell grammatikkundervisning, som i prinsippet kan bygge på reint systemorientert teori, og funksjonell grammatikkteori. Samstundes er det nærliggande å spørje om det ikkje kan vere noko å hente på å legge funksjonell grammatikkteori til grunn for arbeidet med grammatikk i skulen (jf. også Haugen, 2019):

Within the theoretical perspectives offered by Systemic Functional Linguistics, and rhetorical grammar - and the recent empirical work of Fearn and Farnan (2007), Macken-Horarik et al. (2011), Myhill et al. (2012), and Schleppegrell (2007) - there are signs of an emerging consensus that grammar may be important in developing learners' understanding of how language works and, specifically, how grammar choices are significant in shaping and constructing meaning. (Myhill \& Watson, 2014, s. 53)

Ikkje minst er det i funksjonell grammatikkteori eit nærare forhold mellom språksystemet og realiseringa av det i tekstar enn ein finn i reint systemorienterte tilnærmingar, noko som kan gje ei meir heilskapleg forståing, og som kan gje grunnlag for å sjå fleire delar av faget i samanheng.

Både tradisjonell skulegrammatikk og den strukturalistiske tradisjonen, som Faarlund, Lie og Vannebo (1997, s. 7) i ein norsk kontekst kallar «Diderichsen- 
tradisjonen», jf. Diderichsen (1946), er det vi kan kalle systemorienterte tilnærmingar til grammatikk. Utgangspunktet for dei grammatiske beskrivingane er korleis dei språklege einingane kan delast opp og setjast saman, og ein ønskjer å beskrive dette som system uavhengig av korleis dei blir brukte i tekstar. Omgrepet funksjon blir nytta også i desse tradisjonelle tilnærmingane til grammatikk, men det er då snakk om funksjonar i setningar og frasar i isolasjon, særleg om syntaktiske funksjonar som verbal, subjekt og objekt og om funksjonar innanfor ein frase, som kjerne, bestemmar og beskrivar. Sjølv om ein i skulen nok har lagt større vekt på semantiske definisjonar enn i vitskapsfaget, blir slike funksjonar først og fremst definerte ut frå plassering i den syntaktiske strukturen og ut frå det språklege materialet som realiserer dei. I funksjonsorienterte tilnærmingar er det derimot bruk og meining i tekst som i større grad er utgangspunktet for å definere funksjonar.

Legg ein funksjonell grammatisk teori til grunn, og då særleg systemiskfunksjonell grammatikk (Halliday, 2014), som kan hende er det funksjonelle rammeverket som har slege sterkast gjennom i skulen i land med ei slik tilnærming, kan vi skilje mellom to ulike, men beslekta tydingar av termen funksjon. Den første handlar om bruk, det Van Leeuwen (2005, s. 75) kallar "function in society», medan den andre tydinga handlar om den indre organiseringa til språket, som Van Leeuwen (2005, s. 75) kallar «function in structure». Det er denne siste tydinga ein er mest oppteken av på det grammatiske nivået, og då av dei meiningsbaserte funksjonane som delane i språket spelar i større heilskapar der dei blir brukte.

Til skilnad frå reint systemorienterte tilnærmingar legg ein i funksjonelle tilnærmingar større vekt på kontekstualisering av grammatiske fenomen på ulike nivå. Setninga er såleis den sentrale eininga i Hallidays funksjonelle grammatikk, sidan setningar er dei sentrale einingane for utveksling av meiningsinnhald i tekstar. Setningar består av prosessar (verb), deltakarar (substantiv) og omstende, og ord bygger opp ordgrupper som realiserer desse elementa i setningane. Med ei funksjonsorientert tilnærming vil dette vere utgangspunktet, ikkje ordklassane i isolasjon. Samstundes er det ikkje slik at ein med ei slik tilnærming ikkje er oppteken av systemet; innsikt i språk og tekst føreset sjølvsagt at ein får kunnskap om system og delsystem, og ein brukar då òg gjerne termen systemisk-funksjonell lingvistikk om Halliday-skulen. Den viktigaste skilnaden frå reint systemorienterte tilnærmingar er at beskrivinga av systemet er integrert med beskrivingar av tekstar og kontekstar der systemet blir realisert, og dermed blir den grammatiske terminologien dels annleis og meir omfattande. Ei funksjonsorientert tilnærming av denne typen er meir holistisk enn ei reint systemorientert tilnærming.

Skilnaden mellom ei systemorientert og ei funksjonsorientert tilnærming til ordklassar kan oppsummerast slik: Med ei systemorientert tilnærming vil ordklassane i stor grad bli handsama isolert, som eit eige område i den grammatiske beskrivinga. Ein forventar stor vekt på identifisering av einskilde 
ord tilhøyrande dei ulike klassane og på ulike bøyingsformer av ord som kan bøyast. Tilsvarande ventar ein stor vekt på einskildord og bøyingsparadigme som eksempeltypar i pedagogiske framstillingar. Med ei funksjonsorientert tilnærming er det sentralt å beskrive kva for funksjonar enkle språklege einingar spelar i meir komplekse einingar, og ein ventar difor større vekt på dei språklege kontekstane til dei ulike ordklassane, på bruk av ordklassane i tekstar, og på heile setningar og tekstbitar som eksempeltypar i pedagogisk framstilling.

\section{Materiale og koding}

Materialet for undersøkinga er nynorskutgåvene av lærebøker i norsk for 3. og 4. trinn frå fire av dei største lærebokforlaga: Kaleido frå Cappelen Damm (Johansen \& Tovsrud, 2015, 2016), Ordriket frå Fagbokforlaget (Bjerke et al., 2013, 2014), Nye Zeppelin frå Aschehoug (Elsness, 2016, 2017) og Salto frå Gyldendal (Bjerke, Fjeld \& Svanes, 2015). ${ }^{1}$ Til saman omfattar undersøkinga dermed dei aktuelle delane av i alt 30 band. All tekst er gjennomgått, slik at alle omtalar av dei aktuelle ordklassane er med, også utanfor dei spesielt tileigna kapitla. Utvalet er gjort i håp om å gje eit relativt breitt bilete av korleis lærebøker i norskfaget framstiller ordklassane, og dermed korleis dei tolkar og didaktiserer den knappe læreplanformuleringa nemnt i innleiinga. Samstundes kan ikkje resultata nødvendigvis generaliserast til andre læreverk, noko dei relativt store skilnadene mellom læreverka også understrekar.

Læreplanmålet nemner ikkje noko om kva for ordklassar som skal handsamast, og dei fire læreverka opererer heller ikkje med det same utvalet av klassar. Alle fire læreverka har likevel med både verb, substantiv og adjektiv, og vi har difor valt å konsentrere den meir detaljerte undersøkinga om desse ordklassane. Samanliknar vi læreverka elles, ser vi at Kaleido har den mest omfattande handsaminga av andre ordklassar, ved at både personleg pronomen, preposisjonar og konjunksjonar (bindeord) blir handsama her, medan Ordriket har med preposisjonar. Salto og Zeppelin handsamar derimot berre verb, substantiv og adjektiv.

Også når det gjeld omfanget av pedagogisk tekst, er det relativt store skilnader mellom dei fire læreverka, jf. figur 1.

\footnotetext{
${ }^{1}$ Når vi refererer til læreverka som heilskapar, nyttar vi heretter titlane, og vi nyttar kortforma Zeppelin om Nye Zeppelin.
} 


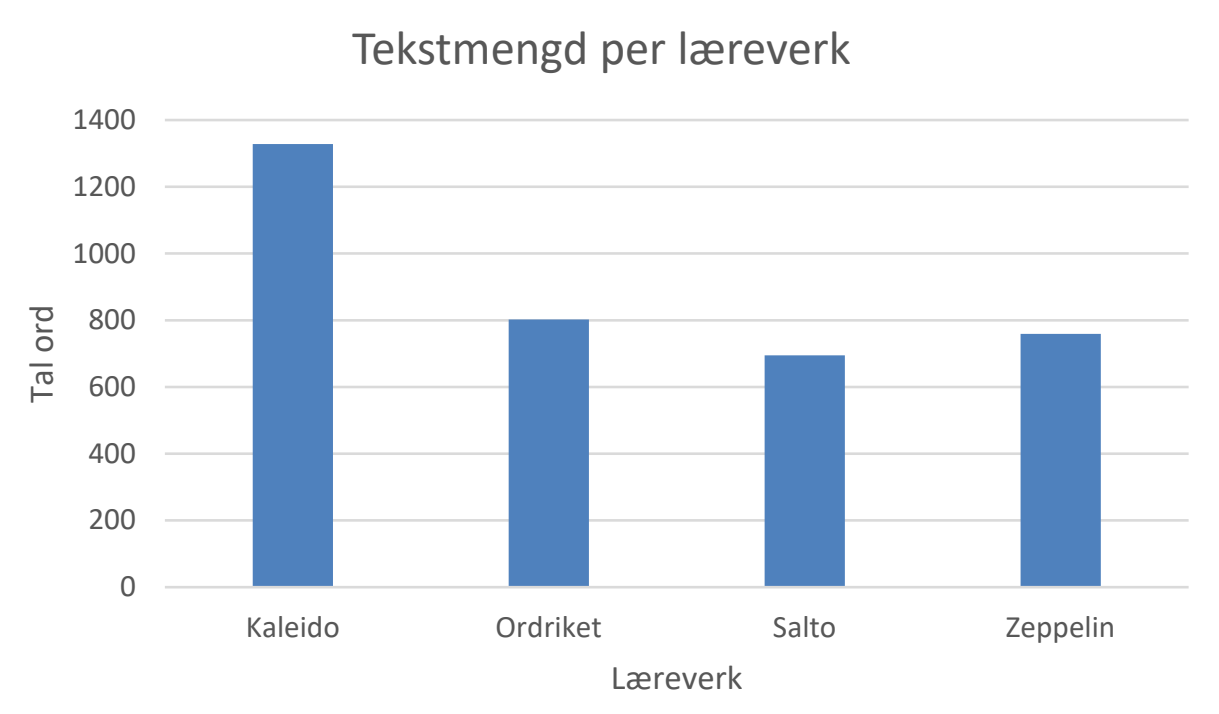

Figur 1: Omfang av pedagogisk tekst per læreverk, oppgåver ekskludert.

Tala i figur 1 inkluderer tekst knytt til ordklassane verb, substantiv og adjektiv, og når vi veit at Kaleido også handsamar fleire ordklassar enn dei andre læreverka, er det klart at Kaleido har eit langt større omfang av pedagogisk tekst om ordklassar enn dei andre læreverka. Tala inkluderer tekstar som gjev eksempel, medan oppgåvene er haldne utanfor.

Dei pedagogiske tekstane om ordklassar i dei fire læreverka kan delast inn i det vi kan kalle forklarande tekstar, eksempel, oppgåver og illustrasjonar. Vi skal her konsentrere oss om dei forklarande tekstane og eksempla. Med forklarande tekstar meiner vi brødteksten og rammer med kortare tekstar der ordklassane blir forklara for elevane. På desse klassetrinna er omfanget av forklarande tekst relativt lite, og utover inndelinga i ulike ordklassar er tekstane i liten grad eksplisitt delte inn i meir spesifikke tema. Innhaldskategoriane må ein såleis identifisere i dei einskilde setningane tekstane består av. Vi opererer dermed med setningar (heilsetningar) og andre setningsekvivalente einingar som dei grunnleggande innhaldseiningane i tekstane, og sidan omfanget av tekst er avgrensa, er det mogleg å analysere alle innhaldseiningane.

Dei setningsekvivalente einingane består nærare bestemt av einingar som ikkje har finitt verbal, og som gjerne står utanfor store skiljeteikn som avgrensar heilsetningar. Dei kan avgrensast av komma, som i følgjande eksempel: «Substantiv - namn på ting (hund), verb - gjereord (klatre), adjektiv beskrivande ord (lang)» (Salto 3 A $\mathrm{B}$ ). ${ }^{2}$ Dette blir rekna som tre setningsekvivalente innhaldseiningar. I det følgjande bruker vi termen innhaldseining både om setningar og setningsekvivalente innhaldseiningar.

Etter inndelinga av tekstane i innhaldseiningar som beskrive over, er innhaldseiningane kategoriserte etter kva hovudinnhald dei har, og metoden for undersøkinga kan beskrivast som kvalitativ innhaldsanalyse (jf. Elo \& Kyngäs,

${ }^{2}$ Sjå referanseseksjonen for oversyn over komponentane i dei ulike læreverka. 
2008; Fauskanger \& Mosvold, 2014; Hsieh \& Shannon, 2005; Mayring, 2000), nærare bestemt det Fauskanger og Mosvold (2014) og Hsieh og Shannon (2005) kallar konvensjonell, kvalitativ innhaldsanalyse, der systemet av innhaldskategoriar blir utvikla, revidert og etablert gjennom ei rekke gjennomlesingar av materialet. Kategoriane i undersøkinga blei såleis induktivt etablerte. Målet med undersøkinga er primært å avdekke kva innhaldet i tekstane er, samstundes som vi ser etter einingar som er eigna til å seie noko om teoretisk orientering, jf. diskusjonen i del 2 over. Deretter gjer vi enkle kvantitative samanlikningar med deskriptiv statistikk.

I dei forklarande tekstane gjev innhaldseiningane informasjon om:

- semantikken til ord i ordklassen isolert (SEM)

- bruken av ord i ordklassane i tekstar (BRU)

- ulike bøyingsformer av ordklassane (FRM)

- grammatiske trekk som ikkje er knytte til bøying (GRM)

- grammatiske underklassar av ordklassane (UND)

- dei meir komplekse språklege konstruksjonane orda inngår i opp til setningsnivået (KON)

- annan informasjon (ANN)

Desse kategoriane av informasjon er også nytta i kodinga av innhaldseiningane, og vi skal i det følgjande gjere greie for grunnlaget for kodinga, og operasjonaliseringane som er gjort for å skilje mellom kategoriane.

I semantikk-kategorien (SEM) har vi informasjon om tydinga til ord i klassen $\mathrm{i}$ isolasjon, og poenget med desse innhaldseiningane er å hjelpe elevane til å skilje ord i den aktuelle ordklassen frå ord i andre ordklassar. Beskrivingar av kva for fenomen i verda ord i klassen viser til, hamnar i denne gruppa. Semantikk inkluderer òg tydingsbeskrivingar knytte til bøyingsformer. Typisk består semantikk-kategorien av innhaldseiningar der subjektet viser til ordklassen, og der hovudverbalet svært ofte er vere, som t.d. i «Verb er ord som beskriv noko vi gjer, eller noko som skjer» (Salto $4 \mathrm{E} \mathrm{A}$ ) og «Eit substantiv kan vere namn på personar» (Zeppelin $3 \mathrm{~S}$ ). Fokuset er her på tydinga til ordet isolert, til skilnad frå kategorien bruk i tekst (BRU), der fokuset nettopp er bruken av orda i tekstar. Typiske døme her er «Når vi skriv, kan vi bruke adjektiv for å beskrive noko» (Salto $3 \mathrm{E} \mathrm{A}$ ) og «Å gjere eit språk rikare betyr å ta med meir informasjon i setningane du skriv» (Kaleido $4 \mathrm{~L} \mathrm{~B}$ ). Den vanlegaste subjektstypen i denne kategorien er det Vareberg (2013) kallar eit situasjonelt, inkluderande «vi» av språkbrukarar, slik som i det første eksempelet, eller eit «du», som viser til den skrivande eleven som lesar av boka. Elles kan subjektet vere noko som viser til skriveprosessen, slik som «Å gjere eit språk rikare» i det andre eksempelet. Direkte eller indirekte har innhaldseiningane i bruk-kategorien fokus på at val av ord og ordformer medfører at vi skaper ulike tydingar i ein tekst: «Nokre verb beskriv kva som skjer meir nøyaktig enn andre. Det gjeld å finne verb som får 
fram akkurat det vi ønskjer å seie» (Salto 3 E A). Den første av desse to innhaldseiningane er eit svært sjeldan tilfelle der subjektet viser til ordklasse, men der fokuset på val gjer at eininga likevel hamnar i kategorien bruk i tekst. Elles er subjektstypen, som beskrive over, godt eigna til å operasjonalisere skiljet mellom semantikk og bruk i tekst.

I kategorien form (FRM) har vi innhaldseiningar som seier noko om dei ulike bøyingsformene til dei tre ordklassane, som alle kan bøyast: «Klatre, klatrar og klatra er ulike former av det same verbet» (Salto $4 \mathrm{E} \mathrm{A}$ ). Kategorien inkluderer også tilfelle der eksplisitt nemnde grammatiske trekk er knytte til ulike bøyingsformer: «Formene heiter infinitiv, presens, preteritum og perfektum» (Ordriket 4 E A). Kategorien grammatiske trekk som ikkje er knytte til bøying (GRM) blir berre nytta når det er snakk om grammatiske trekk som ikkje blir realiserte som bøyingsformer for den aktuelle ordklassen, og gjeld i praksis berre kjønn ved substantiv, som i «Nokre substantiv kan ha to kjønn» (Salto 4 A A) og i «Samnamna har ulike kjønn: hankjønn, hokjønn og inkjekjønn» (Salto 4 E A). Sidan dei begge handlar om grammatiske trekk, er det i mange samanhengar naturleg å sjå kategoriane form og grammatiske trekk som ikkje er knytte til bøying, som éin kategori, noko vi òg dels skal gjere i analysane. Det andre eksempelet på grammatisk trekk over er elles eit døme på ei eining der det blir gjeve informasjon om to kategoriar, nærare bestemt både grammatisk trekk og grammatisk underklasse (UND). I slike tilfelle får innhaldseiningane to taggar (dette gjeld også dei andre kategoriane). Grammatiske underklassar handlar elles i hovudsak om samnamn og særnamn som underklassar av substantiv. For materialet som heilskap er det $22 \%$ av innhaldseiningane som har fått to taggar. Resten (78\%) gjev informasjon om éin av kategoriane.

Kategorien konstruksjon (KON) inneheld innhaldseiningar som seier noko om korleis orda i ordklassane inngår i meir komplekse språklege konstruksjonar, i dei aller fleste tilfelle på frasenivå. Eit typisk døme er ubestemt artikkel som viser kjønnet til substantiv i substantivfrasar: «Føre eit substantiv kan vi skrive anten ein, ei eller eit» (Ordriket 3 A A). Setningsnivå førekjem òg: «Alle setningar må ha minst eitt verb» (Ordriket $4 \mathrm{E} \mathrm{A}$ ).

Endeleg blir kategorien annan informasjon (ANN), som er ein samlekategori for all annan informasjon, berre brukt dersom ei innhaldseining ikkje inneheld informasjon om nokon av dei andre kategoriane. Dette er innhaldseiningar som t.d. «Ord kan vi dele inn i ordklassar» (Zeppelin $4 \mathrm{~S}$ ) og «Vi har lært om ordklassane substantiv og verb» (Zeppelin $4 \mathrm{~S}$ ).

Inndelinga av materialet i innhaldseiningar blei først utført av førsteforfattaren, medan kodinga av einingane også er gjort av medforfattaren. Medforfattaren tok utgangspunkt i det endelege systemet av kategoriar og beskrivinga av desse over, og utførte ei prøvekoding av ein liten del av materialet med etterfølgjande diskusjon. Medfortattaren gjennomførte deretter koding av heile materialet, og samsvaret med førsteforfattarens koding var i den fullstendige kodinga 94,7 \%. Vi diskuterte deretter dei tilfella der det var manglande samsvar, 
og blei einige om endelege val av taggar for dei einskilde innhaldseiningane.

Etter å ha sett på korleis innhaldseiningane i dei pedagogiske tekstane er kategorisert, skal vi no gå over til å sjå på ulike typar av eksempel. Eksempel er sentrale element i denne typen tekstar, og med eitt eksempel meiner vi eitt eller fleire ord, frasar, setningar eller tekstar som står samla utan forklarande tekst mellom, og som eksemplifiserer eitt bestemt fenomen. I hovudsak blir eksempel skilde frå forklarande tekst på tre ulike måtar: (i) Dei følgjer etter ein forklarande tekst med kolon til slutt, (ii) dei er skilde ut med lineskift og står på eigne liner på tekstsida (eventuelt i tabell) eller (iii) dei står i parentesar. Av desse typane kan (i) og (ii) også kombinerast.

I vår samanheng er vi mest interesserte i om eksempla blir gjevne i form av einskildord og bøyingsparadigme, eller om dei viser korleis orda inngår i meir komplekse konstruksjonar og korleis dei blir brukte i setningar og tekstar. Eksempla kan delast inn i følgjande kategoriar:

- einskildord

- bøyingsparadigme

- frase

- setning

- tekst

Einskildord er sjølvsagt isolerte ord frå dei einskilde ordklassane, medan vi med bøyingsparadigme meiner to eller fleire bøyingsformer av det same leksemet. I nokre tilfelle fungerer det som ut frå definisjonen av eksempel over blir rekna som einskildord, også som eksempel på bøyingsparadigme i ein større tekstleg heilskap, og i slike tilfelle reknar vi desse eksempla til begge kategoriar. Slike kombinerte tilfelle utgjer i alt $11 \%$ av eksempla i materialet, medan dei resterande eksempla alle er tilordna éin av kategoriane over. For at eksempel skal reknast som tekst, må det vere snakk om minst to koherente heilsetningar som utgjer ein heilskap, og som ikkje er alternativ til kvarandre.

\section{Resultat}

Kategoriane som er nytta i kodinga av materialet, gjev eit bilete av korleis dei ulike læreverka balanserer det systemorienterte med det funksjons- og tekstorienterte. I tillegg til å sjå på skilnader mellom læreverka er det interessant å sjå på skilnader mellom dei tre ordklassane, og vi skal sjå nærare på dei ulike kategoriane fordelt på ordklassar (4.1) og læreverk (4.2) etter tur. Vi byrjar med nokre samla resultat i denne delen. I materialet som heilskap fordeler kategoriane av innhaldseiningar seg som vist i figur 2. 


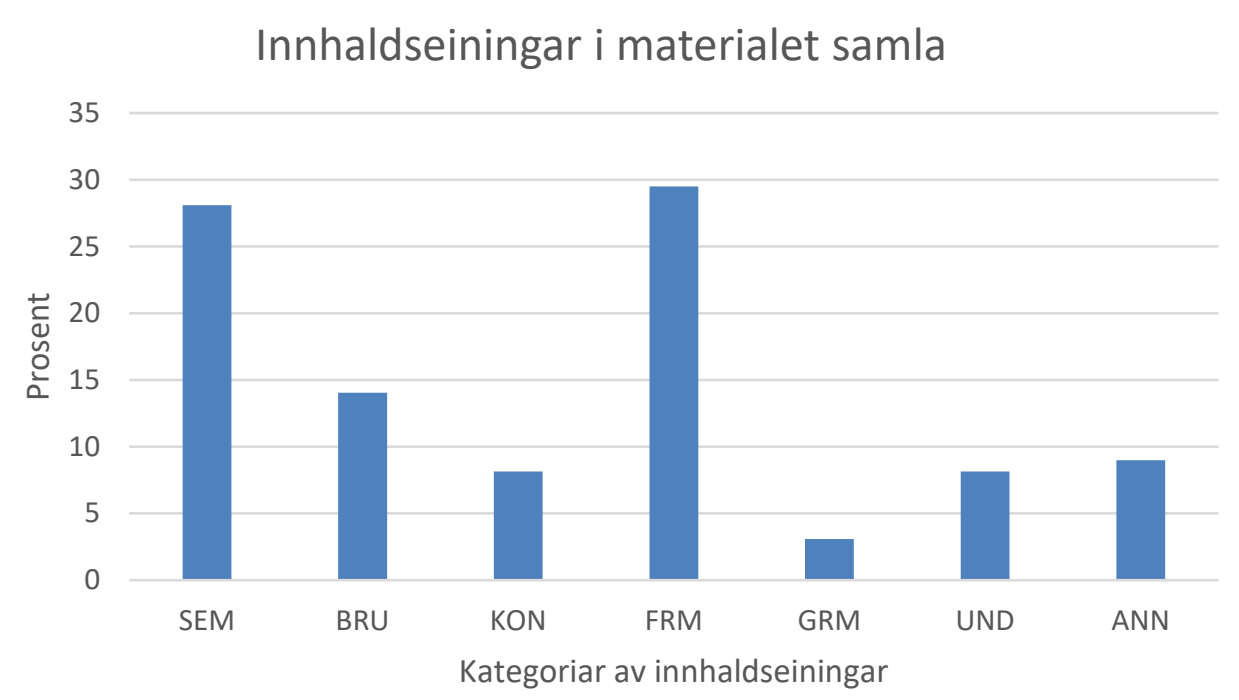

Figur 2: Innhaldseiningar fordelt på kategoriar, tal i prosent.

Som vi ser, er det innhaldseiningar med fokus på bøyingsformer (FRM) på den eine sida og innhaldseiningar med fokus på semantikk (SEM) på den andre som dominerer. Alle dei undersøkte ordklassane har bøying, og det er slik sett ikkje overraskande at det blir lagt ein god del vekt på bøyingsformer. Slår vi saman kategoriane bøyingsformer (FRM) og grammatiske trekk som ikkje er knytte til bøying (GRM), er det $32 \%$ av innhaldskategoriane i materialet samla som inneheld informasjon om dette. Dette er kategoriar med ei klar systemorientering, og vi ser at dette er relativt dominerande i materialet som heilskap. Som vi skal sjå, er det likevel relativt store skilnader mellom læreverka i vektlegginga av dette, og då særleg i høve til kategorien bruk i tekst (BRU), som er den mest funksjonelt orienterte kategorien. Alt i alt er dette langt mindre vektlagt i dei fire læreverka enn semantiske kjenneteikn og bøyingsformer.

Kategorien underklasse (UND) gjeld i hovudsak substantiv, og vi kjem tilbake til denne under omtalen av dei einskilde ordklassane under.

I tillegg til bøyingsformer og andre grammatiske trekk er det dei semantiske innhaldskategoriane som er mest vektlagde. I tradisjonelle tilnærmingar er slike definisjonar typisk pedagogiske hjelpemiddel; meir teoretisk orienterte semantiske tilnærmingar til ordklassar finn ein t.d. i Kognitiv grammatikk (Langacker, 1987, 1991, 2008). Vektlegginga av semantikk er, som vi skal sjå, tydeleg i alle dei fire læreverka, om enn med skilnader. Dei semantiske innhaldseiningane beskriv typisk ulike fenomen som orda i den aktuelle klassen kan vise til i verda, og dei kan såleis vere med på å skape forståing for korleis vi med språket deler inn og skaper bilete av verkelegheita. Det blir også nytta ein del meir abstrakte semantiske beskrivingar. For substantiv går t.d. termar som «ting» og «namn» igjen som semantiske beskrivingar i alle læreverka.

Sjølv om funksjonell grammatikk gjerne har meir fokus på tyding enn meir systemorienterte tilnærmingar, er det verdt å diskutere om semantiske definisjonar kan forståast som funksjonelt orienterte. Fokus på tyding er rett nok i ein viss 
forstand det motsette av fokus på form, men om vi tek utgangspunkt i motsetnaden mellom systemorientert og funksjonsorientert, slik vi gjorde i del 2 over, er fokus på semantikken til isolerte ord eit systemorientert trekk. Det viktigaste poenget med dei semantiske definisjonane er å hjelpe elevane til å skilje medlemmane i éin ordklasse frå medlemmane i andre ordklassar. Med utgangspunkt i funksjonell grammatikk vil det funksjonelle snarare handle om korleis ordklassar realiserer prosessar og deltakarar, som til saman utgjer setningar, som igjen bygger opp tekstar osv.

Kategorien konstruksjon (KON) er, som vi ser, langt mindre frekvent enn semantikk. Med få unntak er konstruksjonar som blir trekte fram av tre typar: (i) artiklar (ein, ei, eit) framfor substantiv, (ii) å framfor infinitiv og (iii) attributive adjektiv i substantivfrasar. Felles for desse er at det i hovudsak ikkje handlar om korleis orda inngår som delar av setningar, men korleis konstruksjonane formelt er oppbygde, og det å kunne identifisere kva for klasse eit ord høyrer til, verkar å vere det viktigaste formålet med å drage inn desse konstruksjonane. Dette kan ein òg sjå som ein naturleg konsekvens av at ein i læreplanen byrjar med ordklassar utan å sjå dei i samanheng med setningsnivået; kompetansemålet for setningsledd og setningsanalyse kjem først etter 7. trinn, noko som ikkje vitnar om ei funksjonsorientert tilnærming. I ei slik tilnærming ville ein forvente at ord, setningsledda dei er ein del av og setningane desse bygger opp, blir handsama i samanheng. Fokuset på ordklassenivået isolert gjer, som vi har vore inne på, også at dei semantiske beskrivingane av ordklassane først og fremst fungerer som hjelp til å kunne bestemme ordklassen til det einskilde ordet, ikkje til å forstå korleis ordet fungerer i større heilskapar.

Setningar, og særleg tekstar, er heller ikkje særleg frekvente mellom eksempla i dei pedagogiske tekstane, som vi skal gå over til å sjå på no. Også eksempla er med på å danne eit bilete av korleis læreverka balanserer funksjonsorienterte og systemorienterte tilnærmingar til grammatikken, og for materialet samla er fordelinga av eksempelkategoriane som vist i figur 3.

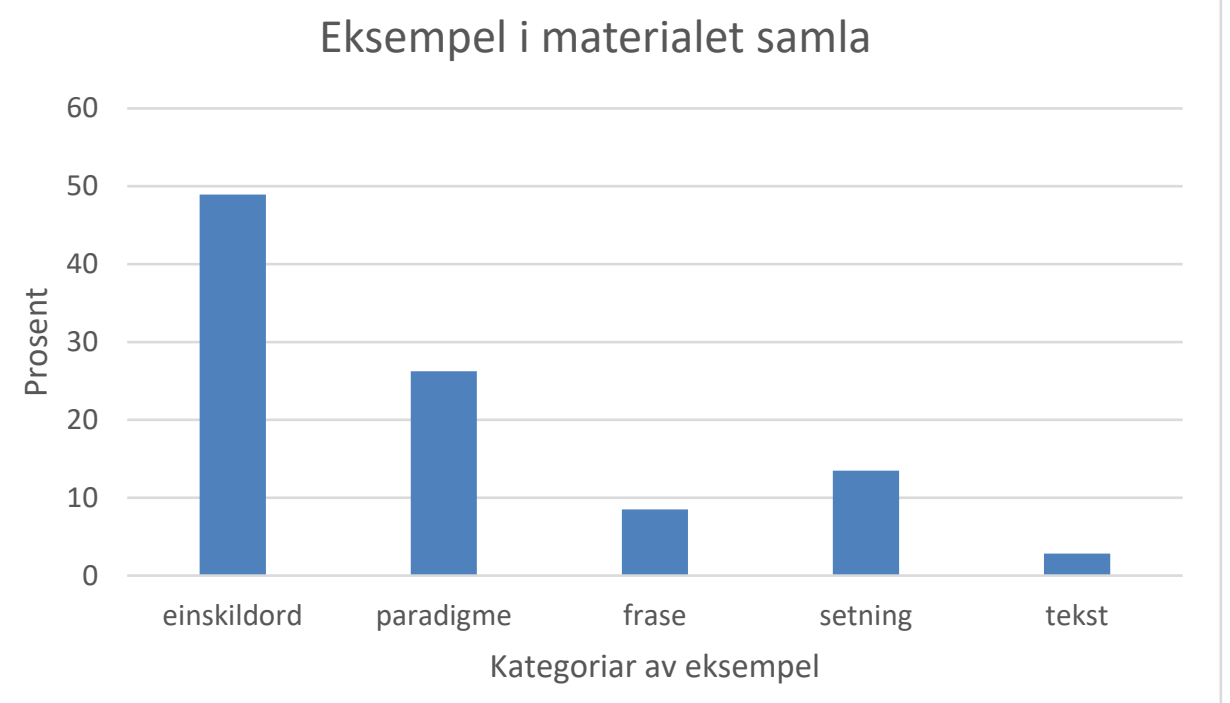

Figur 3: Eksempel fordelt på kategoriar, tal i prosent. 
Vi ser at tekstar, her forstått som einingar som består av fleire koherente heilsetningar, utgjer ein svært liten del av eksempla i dei pedagogiske tekstane. ${ }^{3}$ Dei dominerande eksempeltypane er einskildord og bøyingsparadigme, som til saman utgjer $75 \%$ av eksempla. At setningar ikkje utgjer meir enn $13 \%$, understrekar også at fokuset ikkje er på korleis ordklassane blir brukte for å skape meining i setningar. Alt i alt peikar eksempla klart i retning av eit systemorientert fokus, men som vi skal sjå i del 4.2 under, finn vi også her store variasjonar mellom læreverka. Før vi ser nærare på læreverka, skal vi sjå på skilnader mellom dei einskilde ordklassane i neste del.

\subsection{Ordklassane}

Når det gjeld dei einskilde ordklassane, byrjar vi med eit oversyn over korleis kategoriane av innhaldseiningar fordeler seg på dei ulike ordklassane. Denne distribusjonen er som vist i tabell 1.

Tabell 1: Fordeling av innhaldseiningar etter ordklasse.

\begin{tabular}{|lllllll|}
\hline $\begin{array}{l}\text { Kategoriar } \\
\text { innhaldseiningar }\end{array}$ & \multicolumn{1}{l}{ Substantiv } & \multicolumn{2}{ll}{ Adjektiv } & \multicolumn{2}{l|}{ Verb } \\
& $\%$ & $\mathrm{~N}$ & $\%$ & $\mathrm{~N}$ & $\%$ & $\mathrm{~N}$ \\
SEM (semantikk) & 25 & 31 & 32 & 26 & 27 & 36 \\
BRU (bruk i tekst) & 7 & 9 & 22 & 18 & 9 & 12 \\
KON (konstruksjon) & 10 & 12 & 6 & 5 & 8 & 11 \\
FRM (bøyingsform) & 16 & 20 & 29 & 24 & 47 & 61 \\
GRM (anna grammatisk & & & & & & \\
trekk) & 9 & 11 & 0 & 0 & 0 & 0 \\
UND (underklasse) & 22 & 27 & 2 & 2 & 0 & 0 \\
ANN (anna) & 10 & 12 & 9 & 7 & 8 & 11 \\
sum & 100 & 122 & 100 & 82 & 100 & 131 \\
\hline
\end{tabular}

Vi ser at dei semantiske innhaldseiningane er om lag like frekvente for alle ordklassane. Når det gjeld bruk i tekst, er det klart vanlegast å ha med slik informasjon knytt til adjektiv, og det er om lag dobbelt så mange slike einingar for adjektiv (18) som for substantiv (9) og verb (12). Eit typisk døme på slik bruksinformasjon knytt til adjektiv er følgjande (Kaleido $3 \mathrm{~L} \mathrm{~A}$ ):

Det er lettare å sjå for seg det du fortel om, viss du brukar adjektiv. I staden for å berre seie «Eg har ein venn» kan du for eksempel seie:

- Eg har ein gammal venn

- Eg har ein snill venn

- Eg har ein rik venn

- Eg har ein høg og skjeggete venn

\footnotetext{
${ }^{3}$ Merk at tekstar som er knytte til oppgåver, her er haldne utanfor.
} 
Det er meir vanleg å vise korleis ein med adjektiv kan endre beskrivingar av deltakarar enn korleis ein med verb kan endre prosesstypar og korleis ein med substantiv kan velje deltakarane i setningane. Dermed får beskrivinga av adjektiv eit sterkare funksjonelt fokus enn tilfellet er for dei andre ordklassane. Ein grunn til dette kan sjølvsagt vere at adjektiva ikkje er obligatoriske i substantivfrasen og fritt kan veljast til for å spesifisere, men det tyder ikkje at vala ein gjer av substantiv og verb er mindre viktige, snarare tvert imot.

For kategorien konstruksjon har vi eit omvendt tilhøve; slik informasjon utgjer ein langt mindre del av innhaldseiningane om adjektiv, og då særleg i høve til substantiv. For substantiv er det her ofte snakk om substantivfrasar med ubestemte artiklar, medan det for verb særleg er snakk om infinitivsmerket å og tidsadverb som passar til dei ulike tempusa. For adjektiva blir det av og til nemnt at dei beskriv substantiv, men dette er altså noko mindre frekvent.

Når det gjeld kategoriane bøyingsformer og andre grammatiske trekk, ser vi at dette er mest frekvent for verb, der det blir brukt ein god del plass på dei ulike bøyingsformene knytte til tempus. Kategorien for andre grammatiske trekk er avgrensa til kjønn ved substantiv, der denne kategorien ikkje er ein bøyingskategori.

Kategorien underklasse finst derimot i hovudsak ved substantiv, og det er då snakk om skiljet mellom samnamn og særnamn, som alle læreverka nyttar. Ved adjektiv er det snakk om skilnaden mellom morfologisk og perifrastisk gradbøying, noko som er langt mindre omtalt.

Lat oss no sjå nærare på eksempelkategoriane, som fordelt på ordklassane er distribuerte slik vi ser i tabell 2.

Tabell 2: Fordeling av eksempelkategoriar etter ordklasse.

\begin{tabular}{|lllllll|}
\hline Eksempelkategoriar & \multicolumn{3}{l}{ Substantiv } & \multicolumn{2}{l|}{ Adjektiv } & Verb \\
& $\%$ & $\mathrm{~N}$ & $\%$ & $\mathrm{~N}$ & $\%$ & $\mathrm{~N}$ \\
enkeltord & 55 & 30 & 41 & 11 & 47 & 25 \\
paradigme & 22 & 12 & 30 & 8 & 32 & 17 \\
frase & 20 & 11 & 4 & 1 & 0 & 0 \\
setning & 0 & 0 & 22 & 6 & 19 & 10 \\
tekst & 4 & 2 & 4 & 1 & 2 & 1 \\
sum & 100 & 55 & 100 & 27 & 100 & 53 \\
\hline
\end{tabular}

Vi ser at einskildord er den vanlegaste eksempeltypen for alle ordklassane, og at det er denne eksempelkategorien som dominerer saman med bøyingsparadigme. Ordklassane skil seg frå kvarandre først og fremst når det gjeld bruk av frasar og setningar som eksempel. Bruk av frasar er tydeleg knytt til substantiva, og det er då svært ofte snakk om frasar med ubestemt artikkel. Det er eit viktig poeng at det då er snakk om isolerte frasar, og ikkje om frasar i funksjon som setningsledd. 
Frasekategorien er ikkje særleg relevant for verb, ${ }^{4}$ sidan verbal med underordna ledd vil danne setningar, og vi ser då òg at setningar er omlag like frekvente for verb som frasar er for substantiv. Den mest slåande skilnaden finn vi mellom substantiv og adjektiv: Medan ingen av eksempla med substantiv er setningar, er heile $22 \%$ av eksempla om adjektiv i denne kategorien. Setningane som eksemplifiserer adjektiv, viser adjektiv i attributiv funksjon og gradbøying. Den lite frekvente koplinga av substantiv og setningar understrekar at ein ikkje legg særleg vekt på korleis substantiv utgjer deltakarar i dei prosessane verb uttrykker i setningar, slik ein ville forvente med ei funksjonsorientert tilnærming til grammatikken. Delen tekstar mellom eksempla utgjer også ein svært liten del for alle ordklassane.

\subsection{Læreverka}

Vi har allereie sett (del 3) at det er ulikt kor mange ordklassar som blir handsama i dei ulike læreverka, og kor stort omfanget av pedagogisk tekst om ordklassar er. I det følgjande skal vi ta for oss fleire detaljar og skilnader når det gjeld kategoriar av innhaldseiningar og eksempel. Innhaldseiningane fordeler seg som vist i tabell 3.

Tabell 3: Fordeling av innhaldseiningar etter læreverk.

\begin{tabular}{|llllllllll|}
\hline $\begin{array}{l}\text { Kategoriar } \\
\text { innhaldseiningar }\end{array}$ & \multicolumn{1}{c}{ Kaleido } & \multicolumn{1}{c|}{ Ordriket } & \multicolumn{2}{ll}{ Salto } & \multicolumn{2}{c|}{ Zeppelin } \\
& $\%$ & $\mathrm{~N}$ & $\%$ & $\mathrm{~N}$ & $\%$ & $\mathrm{~N}$ & $\%$ & $\mathrm{~N}$ \\
SEM (semantikk) & 29 & 34 & 20 & 17 & 35 & 27 & 29 & 22 \\
BRU (bruk i tekst) & 24 & 28 & 8 & 7 & 13 & 10 & 7 & 5 \\
KON (konstruksjon) & 10 & 12 & 10 & 9 & 5 & 4 & 5 & 4 \\
FRM (bøyingsform) & 21 & 24 & 38 & 33 & 32 & 25 & 31 & 23 \\
GRM (anna grammatisk & & & & & & & & \\
trekk) & 3 & 4 & 8 & 7 & 0 & 0 & 0 & 0 \\
UND (underklasse) & 5 & 6 & 6 & 5 & 9 & 7 & 15 & 11 \\
ANN (anna) & 8 & 9 & 9 & 8 & 6 & 5 & 13 & 10 \\
sum & 100 & 117 & 100 & 86 & 100 & 78 & 100 & 75 \\
\hline
\end{tabular}

Dei semantiske innhaldseiningane utgjer ein nokolunde like stor del i Kaleido, Salto og Zeppelin (29-35 \%), med Ordriket (20\%) noko under dei andre. Dette læreverket har derimot meir vekt på konstruksjonar i høve til Salto og Zeppelin. Dei relativt sett største skilnadene gjeld derimot vektlegginga av bruk i tekst i høve til bøyingsformer og andre grammatiske trekk. Skilnaden når det gjeld bruk i tekst er illustrert i figur 4, medan bøyingsformer og andre grammatiske trekk blir viste i figur 5.

\footnotetext{
${ }^{4}$ Enkelte grammatiske teoriar opererer rett nok med verbfrasar, men det er neppe aktuelt på dette nivået.
} 


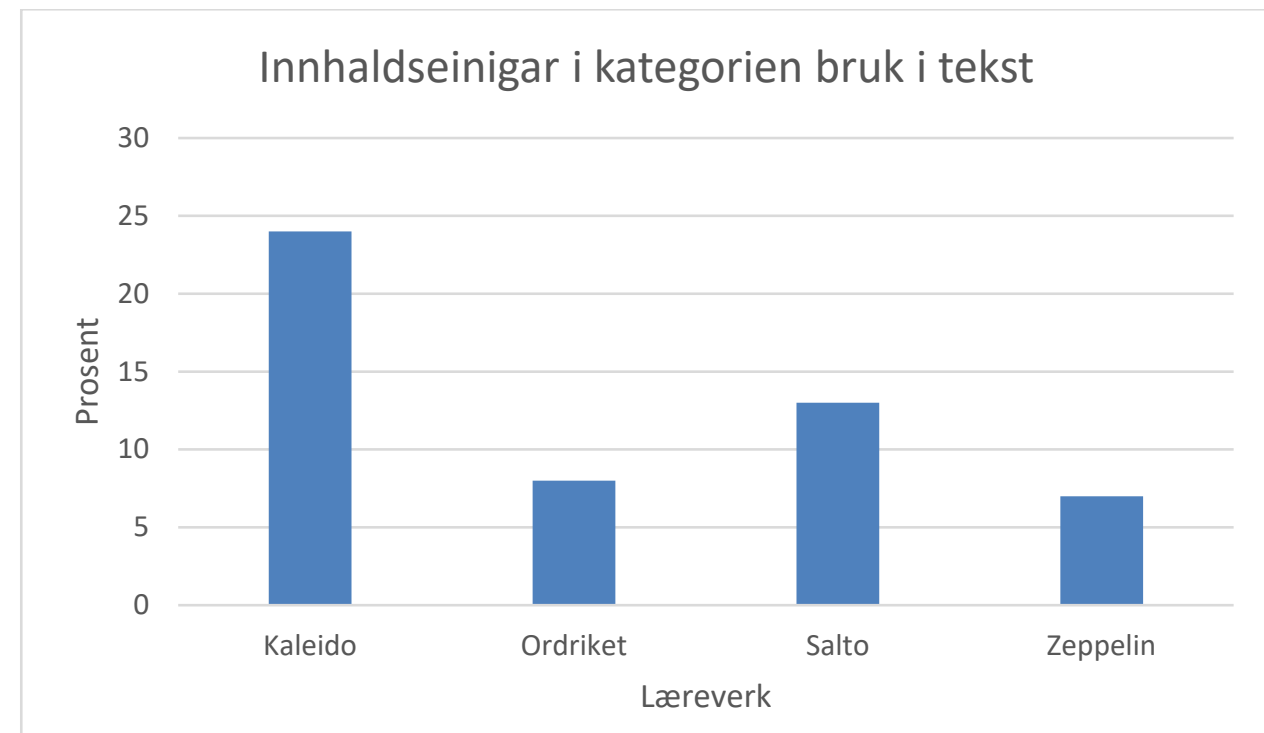

Figur 4: Del innhaldseiningar i kategorien bruk i tekst for kvart læreverk, tal i prosent.

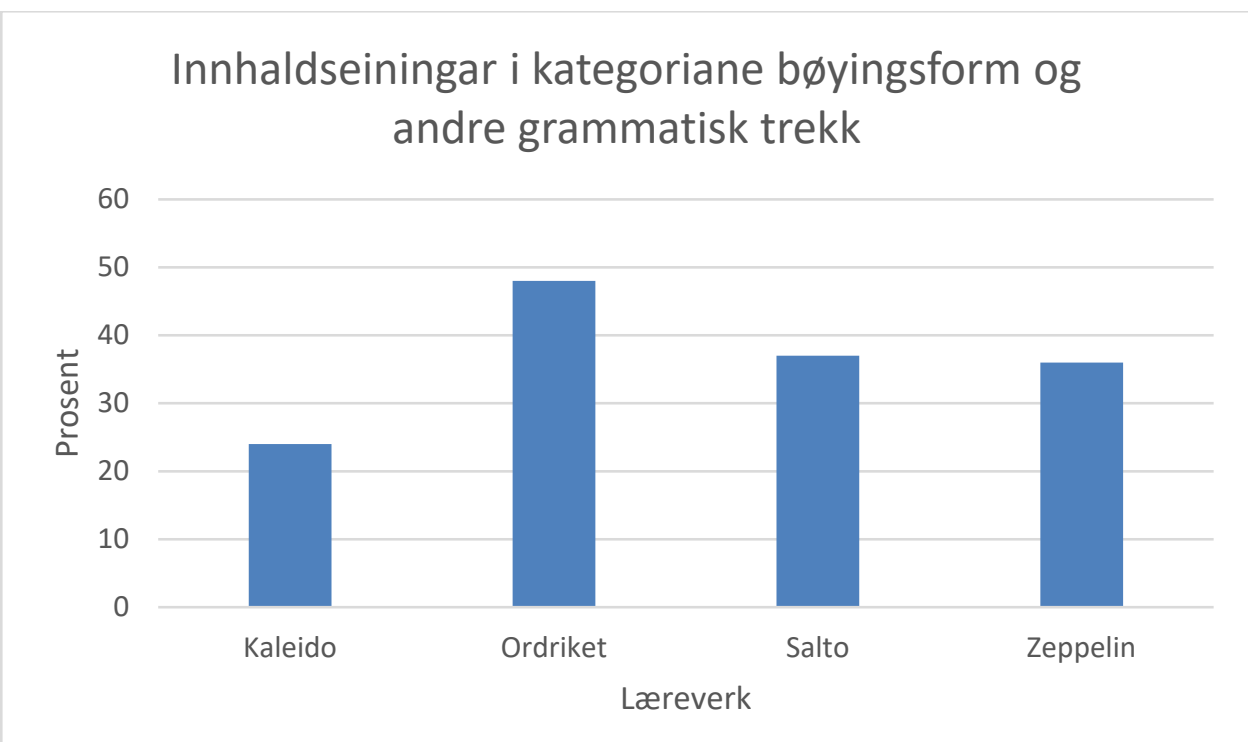

Figur 5: Del innhaldseiningar i kategoriane bøyingsform og andre grammatiske trekk for kvart læreverk, tal i prosent.

Til saman gjev desse resultata eit bilete av Kaleido som læreverket med mest funksjonell vektlegging, medan Ordriket og Zeppelin legg minst vekt på dette. Det er også slik at Kaleido skil seg klart mest ut på dei mest sentrale parametrane i figur 4 og 5, medan tala for dei tre andre læreverka er jamnare, i alle fall om vi ser desse parametrane i samanheng. Det er særleg interessant at Kaleido har ein nesten dobbelt så stor del innhaldseiningar knytt til bruk i tekst i høve til Salto, og tre gonger så stor del i høve til Ordriket og Zeppelin. Og, som vi skal sjå, blir dette resultatet i stor grad stadfesta når vi ser nærare på eksempelkategoriane. Desse fordeler seg på læreverka som vist i tabell 4 . 
Tabell 4: Fordeling av eksempelkategoriar etter læreverk.

\begin{tabular}{|lllllllll|}
\hline Eksempelkategoriar & \multicolumn{3}{c}{ Kaleido } & \multicolumn{2}{c|}{ Ordriket } & \multicolumn{2}{c|}{ Salto } & \multicolumn{3}{c|}{ Zeppelin } \\
& $\%$ & $\mathrm{~N}$ & $\%$ & $\mathrm{~N}$ & $\%$ & $\mathrm{~N}$ & $\%$ & $\mathrm{~N}$ \\
enkeltord & 46 & 18 & 55 & 12 & 50 & 22 & 47 & 17 \\
paradigme & 8 & 3 & 23 & 5 & 36 & 16 & 36 & 13 \\
frase & 10 & 4 & 9 & 2 & 11 & 5 & 3 & 1 \\
setning & 28 & 11 & 14 & 3 & 2 & 1 & 11 & 4 \\
tekst & 8 & 3 & 0 & 0 & 0 & 0 & 3 & 1 \\
sum & 100 & 39 & 100 & 22 & 100 & 44 & 100 & 36 \\
\hline
\end{tabular}

Einskildord er den mest frekvente typen av eksempel i alle læreverka, medan det er relativt store skilnader når det gjeld dei andre kategoriane. Særleg interessante er dei store skilnadene når det gjeld bruk av bøyingsparadigme som eksempel, sjå figur 6. Vektlegging av slike paradigme er eit tydeleg systemorientert trekk, og vi ser at Salto og Zeppelin skil seg ut som dei klart mest systemorienterte læreverka ut frå dette målet. Vidare ser vi at Ordriket her er i ei mellomstilling, medan Kaleido igjen skil seg ut som det minst systemorienterte læreverket.

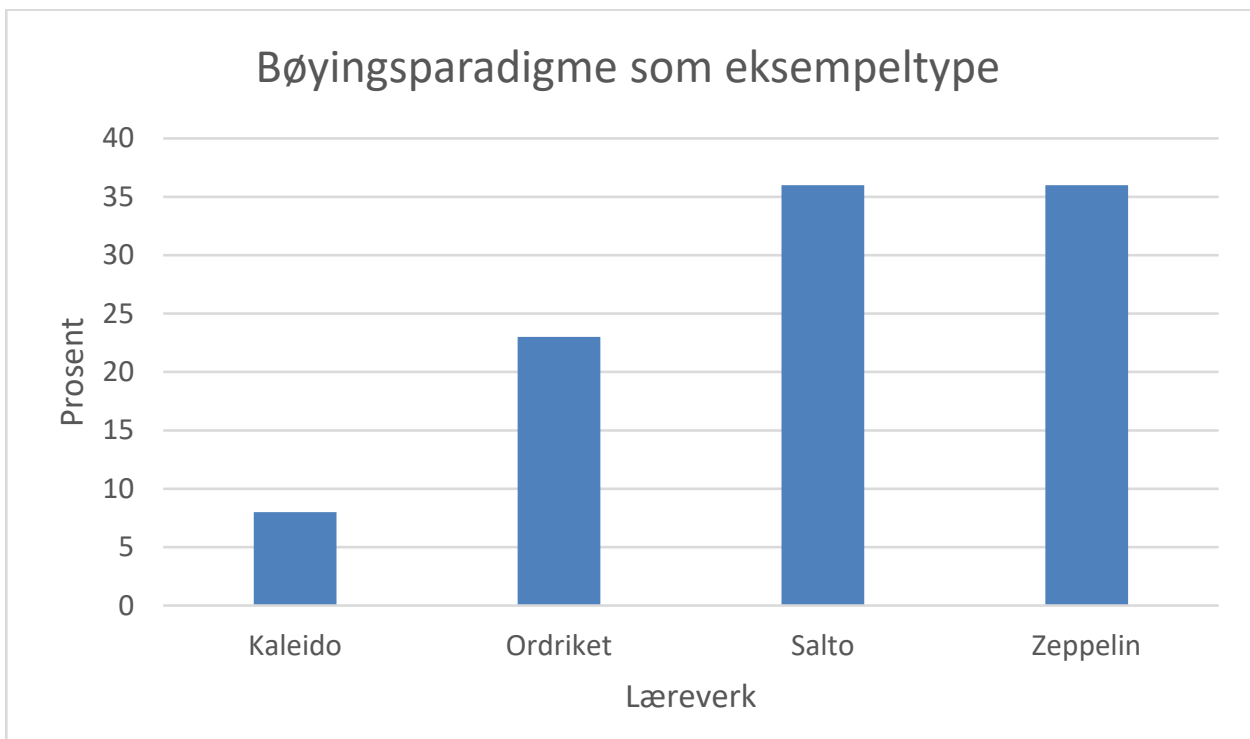

Figur 6: Del bøyingsparadigme som eksempeltype for kvart læreverk, tal i prosent.

Funksjonelt orienterte grammatikktilnærmingar vil ein forvente nyttar fleire setningar og tekstar som eksempel, og dersom vi slår saman desse kategoriane, ser vi kor stor del dei utgjer i dei ulike læreverka i figur 7. Igjen har Kaleido klart størst del av slike eksempel, medan Salto her skil seg klart ut med ein svært liten del. 


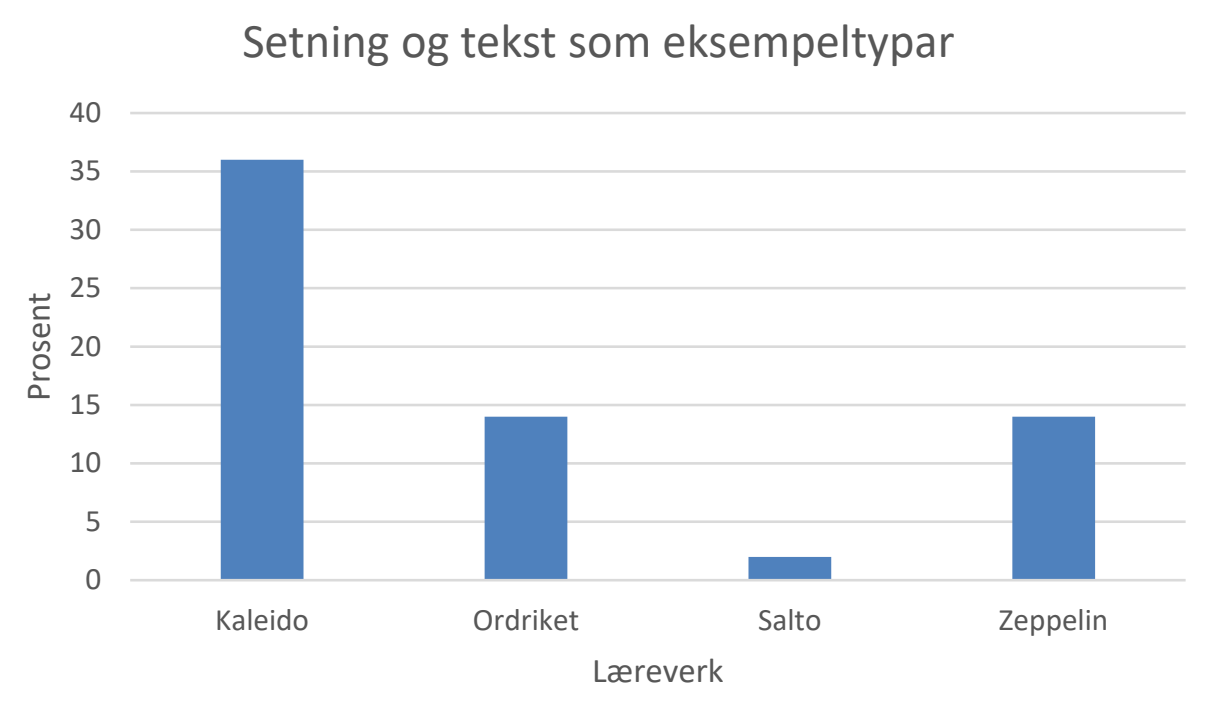

Figur 7: Del setning og tekst som eksempeltypar for kvart læreverk, tal i prosent.

Alt i alt er det relativt store skilnader mellom læreverka også når det gjeld kategoriar av eksempel, og Kaleido er også her det klart mest funksjonelt orienterte læreverket. Og medan det var mindre skilnader mellom dei andre læreverka når det gjaldt innhaldseiningar, skil Salto seg tydeleg ut som det mest systemorienterte læreverket når det gjeld eksempelkategoriar.

\section{Oppsummering, diskusjon og konklusjon}

Kompetansemålet i læreplanen (NOR1-05, s. 7) etter 4. trinn, som eksplisitt handlar om ordklassar, seier, som vi har sett, at elevane skal «beskrive ordklasser og deres funksjon», og det er klart at ei så knapp formulering gjev stort rom for tolking. Undersøkinga har vist ein viss variasjon når det gjeld kva for ordklassar elevane blir presenterte for i læreverk på 3. og 4. trinn. Sidan alle læreverka handsamar substantiv, adjektiv og verb, blei undersøkinga konsentrert om desse tre ordklassane.

Adjektiva skil seg ut frå dei andre ordklassane ved at det er adjektiva det er klart vanlegast å knyte til kategorien vi har kalla bruk i tekst. Etter vårt syn er det eigentleg ingen grunn til å legge meir vekt på korleis adjektiv kan endre korleis deltakarar blir beskrivne enn på korleis ulike prosessar beskriv ulike situasjonar (ved verb) og på korleis substantiv viser til ulike deltakarar i prosessane. Bøyingsformer er elles meir vektlagde ved verb enn ved dei andre ordklassane.

Den vanlegaste eksempeltypen er einskildord og bøyingsparadigme for alle ordklassane, medan setningar, og, særleg, tekstar er mindre brukte. Med eit funksjonelt og tekstorientert fokus i læreplanen skulle ein forvente fleire setningar og tekstar mellom eksempla. Elles er frasar som eksempel, ikkje overraskande, knytte til substantiv, ved at dei får ubestemt artikkel føre seg. Den mest slåande skilnaden når det gjeld eksempel, finn vi mellom adjektiv og substantiv, ved at 
det ved adjektiv er relativt frekvent at setningar blir nytta som eksempel, medan denne eksempeltypen ikkje blir brukt i handsaminga av substantiva. Dette understrekar igjen at adjektiva er den ordklassen der vektlegginga av ei funksjonell tilnærming er størst.

Alle læreverka legg relativt stor vekt på semantiske beskrivingar av ordklassane. Samstundes viser undersøkinga òg at det er relativt store skilnader når det gjeld vektlegging av ei systemorientert versus ei funksjonsorientert tilnærming, noko som ikkje minst kjem fram gjennom ulik vektlegging av bruk i tekst. Kaleido skil seg her ut som læreverket som legg klart mest vekt på dette, medan dette læreverket legg tilsvarande mindre vekt på bøyingsformer og andre grammatiske trekk. Ser vi på eksempla, ser vi den same tendensen. Salto og Zeppelin legg klart mest vekt på bøyingsparadigme som eksempeltype, medan Kaleido har klart minst vekt på dette. Kaleido har derimot klart mest vekt på setningar og tekstar som eksempeltypar.

Som konklusjon kan vi seie at dei pedagogiske tekstane om ordklassar i dei fire læreverka er både systemorienterte og funksjonsorienterte, men i ulik grad. Innsikt i systemet er sjølvsagt ein viktig del av kunnskapen om språk, og det gjev lita meining med funksjonell grammatikk om ein ikkje samstundes får ei forståing for systemet som ligg til grunn. Samanliknar vi læreverka vi har sett på her med nyare lærebøker i norsk språk for lærarstudentar (jf. Haugen 2019 og referansar der), er hovudinntrykket at læreverka til elevane i større grad er både systemorienterte $o g$ funksjons- og tekstorienterte enn framstillinga av ordklassar i nyare lærebøker for lærarstudentar, som i langt mindre grad er tekstorienterte. ${ }^{5}$

Resultatet av undersøkinga viser som nemnt at alle lærebøkene legg relativt stor vekt på semantiske definisjonar og forklaringar av ordklassane, medan beskrivingar knytte til bruk av ordklassane i tekstar er gjennomført i langt meir varierande grad. Svaret på spørsmålet om korleis læreverka balanserer ei systemorientert med ei funksjonsorientert tilnærming til grammatikk, er også eit spørsmål om korleis ein ser på dei semantiske beskrivingane i dei pedagogiske tekstane. Ser ein desse som funksjonelt orienterte, er det langt større balanse mellom systemorientering og funksjonsorientering enn om ein ser på desse innhaldseiningane som systemorienterte. Med grunnlag i funksjonell grammatisk teori inneber ei funksjonell tilnærming til ordklassar at ein legg vekt på korleis dei blir brukte for å realisere prosessar og deltakarar i setningar og tekstar, og i så fall framstår læreverka på dei trinna vi har sett på, som langt mindre funksjonelt orienterte. Årsaka til dette kan vi seie er følgjande paradoks som er innebygt i den progresjonen læreplanen legg opp til: Elevane skal i den første grammatikkopplæringa få ei innføring i funksjonen til ordklassane, medan analysen av setningar, der funksjonane blir realiserte, ikkje kjem som kompetansemål før etter 7. trinn, der det heiter at elevane skal kunne «utføre

\footnotetext{
${ }^{5}$ Eit unntak her er Iversen, Otnes og Solem (2011), som er sterkt tekstorientert.
} 
grunnleggende setningsanalyse og vise hvordan tekster er bygd opp med begreper fra grammatikk og tekstkunnskap» (NOR5-01, s. 8).

Det er interessant å registrere at ein i den australske læreplanen, som i stor grad bygger på innsikter frå systemisk-funksjonell grammatikk, legg opp til at elevane skal arbeide med setningsfunksjonar som prosessar, deltakarar og omstende allereie frå første skuleår (Derewianka, 2011, s. 14). Det er også gledeleg at ein i den nye læreplanen for norsk som skal gjelde frå 1.8.2020, legg opp til at elevane etter 4. trinn skal kunne «bruke fagspråk om setningsoppbygning og bøying av verb, substantiv og adjektiv i samtaler om språk og om egne og andres tekster» (NOR1-06, 2019, s. 5), som, om ein legg godviljen til, kan tolkast slik at setningsfunksjonar skal handsamast saman med ordklassane. Det er også oppløftande at eit av dei nye kjerneelementa er «Språket som system og mulighet», som må tolkast som ei integrert tilnærming til språksystemet og realiseringa av det $\mathrm{i}$ tekst.

Så lenge ein i første omgang i stor grad legg opp til å handsame ordklassane i isolasjon, blir det kan hende vanskeleg å fullt ut skape ei første forståing for funksjonane dei har, og ein oppnår kan hende i mindre grad det metaspråklege medvitet ein er ute etter, og som studiar som Myhill et al. (2012) tyder på kan oppnåast dersom ein legg funksjonell og integrert grammatikkundervisning til grunn for arbeidet med det grammatiske metaspråket i skulen. Som MackenHorarik et al. (2015) peikar på, fordrar ei funksjonell, holistisk tilnærming til grammatikk i skulen at også lærarane får kunnskap om denne måten å forstå og undervise grammatikk på. Lærebøker kan vere ei støtte for lærarane ved å vise korleis ein kan skape forståing for ordklassane i lys av funksjonane dei kan ha i tekstar, og kan såleis potensielt gje viktige bidrag til grammatikkdidaktikkens kva og korleis.

\section{Om forfattarane}

Tor Arne Haugen er professor i norsk ved Høgskulen i Volda. Forskingsinteressene hans omfattar mellom anna funksjonell grammatikk og tilhøvet mellom språk og læring.

Institusjonstilknyting: Institutt for språk og litteratur, Høgskulen i Volda, Postboks 500, 6101 Volda.

E-post: tor.arne.haugen@hivolda.no

Eivor Finset Spilling er stipendiat ved Høgskulen i Volda. Forskingsinteressene hennar er mellom anna grammatikk og byrjaropplæring.

Institusjonstilknyting: Avdeling for humanistiske fag og lærarutdanning, Høgskulen i Volda, Postboks 500, 6101 Volda.

E-post: eivor.finset.spilling@hivolda.no 


\section{Undersøkte læreverk:}

Kaleido 3 L A:

Johansen, R. \& Tovsrud, M. J. (2015). Kaleido 3 Lese- og språkbok A. Oslo: Cappelen Damm.

Kaleido 3 L B:

Johansen, R. \& Tovsrud, M. J. (2015). Kaleido 3 Lese- og språkbok B. Oslo: Cappelen Damm.

Kaleido 3 A A:

Johansen, R. \& Tovsrud, M. J. (2015). Kaleido 3 Arbeidsbok A. Oslo: Cappelen Damm.

Kaleido 3 A B:

Johansen, R. \& Tovsrud, M. J. (2015). Kaleido 3 Arbeidsbok B. Oslo: Cappelen Damm.

Kaleido 4 L A:

Johansen, R. \& Tovsrud, M. J. (2016). Kaleido 4 Lese- og språkbok A. Oslo: Cappelen Damm.

Kaleido 4 L B:

Johansen, R. \& Tovsrud, M. J. (2016). Kaleido 4 Lese- og språkbok B. Oslo: Cappelen Damm.

Kaleido 4 A A:

Johansen, R. \& Tovsrud, M. J. (2016). Kaleido 4 Arbeidsbok A. Oslo: Cappelen Damm.

Kaleido 4 A B:

Johansen, R. \& Tovsrud, M. J. (2015). Kaleido 3 Arbeidsbok B. Oslo: Cappelen Damm.

Ordriket 3 L A:

Bjerke, C., Brandrud, K., Garmann, G. A., Mæhle, L., Strømdahl, T. \& Ulland, G. (2013). Ordriket: Lesebok 3A. Bergen: Fagbokforlaget.

Ordriket 3 L B:

Bjerke, C., Brandrud, K., Garmann, G. A., Mæhle, L., Strømdahl, T. \& Ulland, G. (2013). Ordriket: Lesebok 3B. Bergen: Fagbokforlaget. 
Ordriket 3 A A:

Bjerke, C., Brandrud, K., Garmann, G. A., Mæhle, L., Strømdahl, T. \& Ulland, G. (2013). Ordriket: Arbeidsbok 3A. Bergen: Fagbokforlaget.

Ordriket 3 A B:

Bjerke, C., Brandrud, K., Garmann, G. A., Mæhle, L., Strømdahl, T. \& Ulland, G. (2013). Ordriket: Arbeidsbok 3B. Bergen: Fagbokforlaget.

Ordriket 4 E A:

Bjerke, C., Garmann, G. A., Hagen, M. M., Mæhle, L., \& Ulland, G. (2014). Ordriket: Elevbok 4A. Bergen: Fagbokforlaget.

Ordriket 4 E B:

Bjerke, C., Garmann, G. A., Hagen, M. M., Mæhle, L., \& Ulland, G. (2014). Ordriket: Elevbok 4B. Bergen: Fagbokforlaget.

Salto 3 E A:

Bjerke, K. K., Fjeld, S. M. \& Svanes, I. K. (2015). Salto 3: Elevbok A. Oslo: Gyldendal.

Salto 3 E B:

Bjerke, K. K., Fjeld, S. M. \& Svanes, I. K. (2015). Salto 3: Elevbok B. Oslo: Gyldendal.

Salto 3 A A:

Bjerke, K. K., Fjeld, S. M. \& Svanes, I. K. (2015). Salto 3: Arbeidsbok A. Oslo: Gyldendal.

Salto 3 A B:

Bjerke, K. K., Fjeld, S. M. \& Svanes, I. K. (2015). Salto 3: Arbeidsbok B. Oslo: Gyldendal.

Salto $4 \mathrm{E}$ A:

Bjerke, K. K., Fjeld, S. M. \& Svanes, I. K. (2016). Salto 4: Elevbok A. Oslo: Gyldendal.

Salto 4 E B:

Bjerke, K. K., Fjeld, S. M. \& Svanes, I. K. (2016). Salto 4: Elevbok B. Oslo: Gyldendal.

Salto 4 A A:

Bjerke, K. K., Fjeld, S. M. \& Svanes, I. K. (2016). Salto 4: Arbeidsbok A. Oslo: Gyldendal. 
Salto 4 A B:

Bjerke, K. K., Fjeld, S. M. \& Svanes, I. K. (2016). Salto 4: Arbeidsbok B. Oslo: Gyldendal.

Zeppelin $3 \mathrm{~S}$ :

Elsness, T. F. (2016). Nye Zeppelin 3: Språkbok. Oslo: Aschehoug.

Zeppelin $3 \mathrm{~L}$ :

Elsness, T. F. (2016). Nye Zeppelin 3: Lesebok. Oslo: Aschehoug.

Zeppelin 3 A S:

Elsness, T. F. (2016). Nye Zeppelin 3: Arbeidsbok til språkbok. Oslo: Aschehoug.

Zeppelin 3 A L:

Elsness, T. F. (2016). Nye Zeppelin 3: Arbeidsbok til lesebok. Oslo: Aschehoug.

Zeppelin $4 \mathrm{~S}$ :

Elsness, T. F. (2017). Nye Zeppelin 4: Språkbok. Oslo: Aschehoug.

Zeppelin $4 \mathrm{~L}$ :

Elsness, T. F. (2017). Nye Zeppelin 4: Lesebok. Oslo: Aschehoug.

Zeppelin 4 A S:

Elsness, T. F. (2017). Nye Zeppelin 4: Arbeidsbok til språkbok. Oslo: Aschehoug.

Zeppelin 4 A L:

Elsness, T. F. (2017). Nye Zeppelin 4: Arbeidsbok til lesebok. Oslo: Aschehoug.

\section{Referanser}

Aamotsbakken, B. \& Knudsen, S. V. (2008). Tekst som flytter grenser: Om Staffan Selanders "pedagogiske tekster". Oslo: Novus.

Andrews, R., Torgerson, C., Beverton, S., Freeman, A., Locke, T., Low, G., Robinson, A. \& Zhu, D. (2006). The effect of grammar teaching on writing development. British Educational Research Journal, 32(1), 39-55.

Bakken, J. \& Andersson-Bakken, E. I. (2016). Forståelser av skjønnlitteratur og sakprosa i norskfagets oppgavekultur. Sakprosa, 8(3), 1-36.

Derewianka, B. (2011). A new grammar companion for teachers (2. utg.). Newtown: Primary English Teaching Association Australia.

Diderichsen, P. (1946). Elementær dansk Grammatik. København: Gyldendal.

Elo, S. \& Kyngäs, H. (2008). The qualitative content analysis process. Journal of Advanced Nursing, 62(1), 107-115. https://doi.org/10.1111/j.1365-2648.2007.04569.x

Faarlund, J. T., Lie, S., \& Vannebo, K. I. (1997). Norsk referansegrammatikk. Oslo: Universitetsforlaget. 
Fauskanger, J. \& Mosvold, R. (2014). Innholdsanalysens muligheter i utdanningsforskning. Norsk pedagogisk tidsskrift, 98(02), 127-139.

Fearn, L. \& Farnan, N. (2007). When Is a verb? Using functional grammar to teach writing. Journal of Basic Writing, 26, 63-87.

Gilje, Ø. (2016). Med ARK\&APP: Bruk av lceremidler og ressurser for læring på tvers av arbeidsformer. Universitetet i Oslo. https:/www.uv.uio.no/iped/forskning/prosjekter/arkapp/arkapp_syntese_endelig_til_trykk.pdf

Grammatiske termer til bruk i skoleverket. (2005). Norsk språkråd og Utdanningsdirektoratet. https://www.udir.no/Upload/Rapporter/5/Grammatisk_terminologi.pdf

Halliday, M. A. K. (2014). Introduction to Functional grammar (4. utg.). London: Routledge.

Haugen, T. A. (2019). Funksjonell grammatikk som metaspråk i skulen - Ei moglegheit for djupnelæring i arbeid med språk og tekst. Acta Didactica Norge, 13(1), Art. 9, 22 sider. https://doi.org/10.5617/adno.6240

Hertzberg, F. (1990). “- og denne Videnskab har man kaldet Grammatiken”: Tre studier i skolegrammatikkens historie. Doktoravhandling. Universitetet i Oslo.

Hertzberg, F. (1995). Norsk grammatikkdebatt i historisk lys. Oslo: Novus.

Hertzberg, F. (2004). Hva har skjedd med problembarnet? Grammatikken og norskfaget nok en gang. I P. Hamre, O. Langlo, O. Monsson \& H. Osdal (red.), Fag og fagnad: Festskrift til Kjell-Arild Madssen i høve 60-årsdagen (s. 97-111). Volda: Høgskulen i Volda.

Hsieh, H.-F. \& Shannon, S. E. (2005). Three approaches to qualitative content analysis. Qualitative Health Research, 15(9), 1277-1288. https://doi.org/10.1177/1049732305276687

Iversen, H. M., Otnes, Hildegunn \& Solem, M. S. (2011). Grammatikken i bruk (3. utg.). Oslo: Cappelen Damm Akademisk.

Johnsen, E. B. (1999). Lœrebokkunnskap: Innføring i sjanger og bruk. Oslo: Tano Aschehoug. http://urn.nb.no/URN:NBN:no-nb_digibok_2009040304070

Johnsen, E. B. (2001). Textbooks in the kaleidoscope: A critical survey of literature and research on educational texts. Tønsberg: Høgskolen i Vestfold. http://urn.nb.no/URN:NBN:no-nb_digibok_2007112801032

Juuhl, G. K., Hontvedt, M. \& Skjelbred, D. (2010). Leremiddelforsking etter LK06: Eit kunnskapsoversyn. Høgskolen i Vestfold. https://openarchive.usn.no/usnxmlui/handle/11250/149132

Karsrud, K. (2014). Grammatikkens nytteverdi i skulen: Ein kritisk diskursanalyse av lcereplanane frå 1939 til 2013. Masteroppgåve, Høgskolen i Sør-Trøndelag. http://hdl.handle.net/11250/224658

Knudsen, S. V. (2013). Pedagogiske tekster og ressurser i praksis. Oslo: Cappelen Damm akademisk.

Knudsen, S. V. \& Aamotsbakken, B. (2010a). Refleksioner over pædagogiske tekster. I S. V. Knudsen \& B. Aamotsbakken (red.), Teoretiske tilncrminger til pedagogiske tekster (s. 13-31). Kristiansand: Høyskoleforlaget.

Knudsen, S. V. \& Aamotsbakken, B. (2010b). Teoretiske tilnæerminger til pedagogiske tekster. Kristiansand: Høyskoleforlaget.

Kolln, M. \& Gray, L. (2016). Rhetorical grammar: Grammatical choices, rhetorical effects (8. utg.). Boston: Pearson.

Langacker, R. W. (1987). Foundations of Cognitive Grammar: Theoretical prerequisites (Bd. 1). Stanford: Stanford University Press.

Langacker, R. W. (1991). Foundations of Cognitive Grammar: Descriptive application (Bd. 2). Stanford: Stanford University Press.

Langacker, R. W. (2008). Cognitive Grammar: A basic introduction. Oxford: Oxford University Press. 
Macken-Horarik, M., Love, K. \& Unsworth, L. (2011). A grammatics “good enough” for school English in the 21st century: Four challenges in realising the potential. Australian Journal of Language and Literacy, 34(1), 9-23.

Macken-Horarik, M., Sandiford, C., Love, K. \& Unsworth, L. (2015). New ways of working 'with grammar in mind' in school English: Insights from systemic functional grammatics. Linguistics and Education, 31, 145-158. https://doi.org/10.1016/j.linged.2015.07.004

Mayring, P. (2000). Qualitative content analysis. Forum Qualitative Sozialforschung / Forum: Qualitative Social Research, 1(2). https://doi.org/10.17169/fqs-1.2.1089

Myhill, D. A., Jones, S. M., Lines, H. \& Watson, A. (2012). Re-thinking grammar: The impact of embedded grammar teaching on students' writing and students' metalinguistic understanding. Research Papers in Education, 27(2), 139-166.

https://doi.org/10.1080/02671522.2011.637640

Myhill, D., Jones, S., Watson, A. \& Lines, H. (2013). Playful explicitness with grammar: A pedagogy for writing. Literacy, 47(2), 103-111. https://doi.org/10.1111/j.17414369.2012.00674.x

Myhill, D. \& Watson, A. (2014). The role of grammar in the writing curriculum: A review of the literature. Child Language Teaching and Therapy, 30(1), 41-62. https://doi.org/10.1177/0265659013514070

Myrmo, J. B. (1998). Grammatikkdebatten før og nå. Norsklæreren 1998 (5), 5-9.

NOR1-05. (2013). Lereplan i norsk. Utdanningsdirektoratet. http://data.udir.no/kl06/NOR105.pdf

NOR1-06. (2019). Læreplan i norsk. Utdanningsdirektoratet. https://data.udir.no/kl06/v201906/laereplaner-lk20/NOR01-06.pdf

Schleppegrell, M. J. (2007). At last: The meaning in grammar. Research in the Teaching of English, 42(1), 121-128.

Schleppegrell, M. J. (2013). The role of metalanguage in supporting academic language development. Language Learning, 63(s1), 153-170. https://doi.org/10.1111/j.14679922.2012.00742.x

Selander, S. (1988). Lärobokskunskap: Pedagogisk textanalys med exempel från läroböcker i historia 1841-1985. Lund: Studentlitteratur.

Selander, S., \& Skjelbred, D. (2004). Pedagogiske tekster for kommunikasjon og læring. Oslo: Universitetsforlaget.

Sellevoll, M. B. (2016). Grammatikk og didaktikk. En studie av 12-åringers grammatikkunnskaper generelt og betydningen av montessoripedagogisk undervisningsmetode spesielt. Masteroppgåve, Universitetet i Bergen. https://bora.uib.no/handle/1956/12063

Skrunes, N. (2010). Lerebokforskning: En eksplorerende presentasjon med scerlig fokus på kristendomskunnskap, KRL og religion og etikk. Oslo: Abstrakt forlag.

Terminologien i norsk språklære. (1977). Norsk språkråd. Oslo: Cappelen. http://urn.nb.no/URN:NBN:no-nb_digibok_2007072704027

Tiller, M. L. (2016). Med grammatikk som verktøy: En komparativ analyse av to lerebøkers formidling av grammatiske språktrekk som potensielle verktøy i skriving av sakprega tekster. Masteroppgåve, NTNU. https://ntnuopen.ntnu.no/ntnuxmlui/handle/11250/2403446

Trygsland, G. (2017). Hva kjennetegner grammatikkundervisningen i tre norske klasserom? Masteroppgåve, Universitetet i Oslo. https://www.duo.uio.no/handle/10852/58067

Van Duijn, I. (2016). Ulike land, ulik grammatikkundervisning?: Ei komparativ undersøking av ulike syn på grammatikkundervisninga i lcereplanar og lareverk frå Noreg og Nederland. Masteroppgåve, Høgskulen i Sogn og Fjordane. https://hvlopen.brage.unit.no/hvlopen-xmlui/handle/11250/2407019 
Van Leeuwen, T. (2005). Introducing social semiotics. London: Routledge.

Vareberg, O. C. (2013). "Vi har lært mye svensk av Emil i Lønneberget”: Vi-konstruksjoner i norskfaglige lærebøker. In S. V. Knudsen (red.), Pedagogiske tekster og ressurser i praksis (s. 59-82). Oslo: Cappelen Damm akademisk. 